\title{
The Transatlantic Relation in Times of Multipolarity: European Security Implications
}

\author{
Cristian Iordan *
}

\begin{abstract}
Freedom does not come for free. And any decisions taken to improve our economy must not lead us into a different sort of crisis - a security crisis.
\end{abstract}

Anders F. Rasmussen ${ }^{1}$

\section{Introduction}

The economic growth generated by the globalization of the world economy over the past several decades has supported the rise of emerging powers. This in turn is leading to an expected change in the international system, giving rise to theories of a multipolar or a polycentric world, with higher interdependencies and multiple poles of power. Nevertheless, the consequences of the global financial crisis are currently challenging these theories and forecasts. At the transatlantic level, the combination of several trendssuch as continuously shrinking defense budgets and declining public and political interest in NATO on both sides of the Atlantic, and a greater strategic emphasis in the U.S. on the Asia-Pacific region - could affect the United States' level of engagement in Europe and, consequently, in Europe's security.

Europe would find itself in a weak spot, facing difficulties in dealing with the possible (military, humanitarian, etc.) crises in its neighborhood, at least in the short to medium term. Yet Europe holds at least some of the right cards in order to remain a relevant actor in the future, based on its economy, internal structure, and functioning; it is well positioned to play an important role at the international and multinational level. In order to achieve this future state, Europe must dedicate thought and resources. The continuation and deepening of the transatlantic relation - even if not on an exclusive footing - would be a natural response to the challenges of the twenty-first century, and would prove beneficial to both sides of the Atlantic.

\footnotetext{
Cristian Iordan works in the area of cyber security as a specialist in international cooperation. His areas of interest and study include security, defense, terrorism, civil liberties, human rights, intelligence, critical infrastructure protection and cyber security, particularly at the level of the European Union. He holds a master's degree in international relations and a Ph.D. in political science from the University of Bucharest. He is also a 2011 graduate of the Program in Advanced Security Studies at the Marshall Center and a 2013 Marshall Center Scholar.

1 Keynote speech by NATO Secretary General Anders Fogh Rasmussen at the NATO Parliamentary Assembly in Prague, 12 November 2012; available at http://www.nato.int/cps/en/SID68853CD7-CAC1A3AE/natolive/opinions_91210.htm.
} 


\section{The Emerging Twenty-First Century Security Environment: From Unipolarity to Multipolarity?}

The end of World War II marked the beginning of a relatively stable international system, with two great powers - the United States and the Soviet Union-dominating global economic, political, and military affairs. With the end of the Cold War, the fall of communism in Central and Eastern Europe, and the dissolution of the USSR in 1991, the U.S. survived as the world's only superpower, and the world entered the unipolar era. Yet, as Jan Andersson notes, "Nevertheless, some twenty years later, military overextension and reckless economic policies have weakened the U.S to the point where it is unable to maintain its dominant role in international affairs." 2

\section{Visions}

At this point, there are several perspectives on potential future states for the world system: the world could be entering a new phase, with higher interdependencies and multiple poles or centers of power, becoming multipolar or polycentric. The economic growth generated by the globalization of the economy has supported the rise of developing powers - the BRICS ${ }^{3}$ and others - which is expected to lead to a change in the international system. The forecasts for the world of 2030 are founded on this trend of power diffusion among countries of the world. ${ }^{4}$ On the other hand, several authors speak of an age of apolarity, an anarchic world (Niall Ferguson, Zbigniew Brzezinski), or even of "another Great American Century" (Richard Haass).

Numerous studies focus on the rise of the Asia-Pacific region in the balance of world economics and political power, stating, for instance, that Europe and North America combined will be surpassed "in terms of power (calculated from GDP, population, defense spending, investments in technology) by 2030, if not earlier. Not only Europe and the United States are projected to decline, but so are Japan and Russia."5 Following the relative economic success of the rising powers, and also miscalculations, mistakes, and weaknesses from the U.S. side, the world would consist of no hegemon, but rather several powers (U.S., China, India, Brazil, Russia, even South Africa—and, optimistically,

2 Jan Joel Andersson, “The Transatlantic Relationship," Swedish Institute of International Affairs (UI) (2013).

3 Brazil, Russia, India, China and, since 2010, South Africa.

4 These include "Global Trends 2030: Alternative Worlds," The National Intelligence Council (available at http://www.dni.gov/files/documents/GlobalTrends_2030.pdf) and "Citizens in an Interconnected and Polycentric World. Global Trends 2030," from the European Union's Institute for Security Studies (available at www.iss.europa.eu/uploads/media/ESPAS_report_ 01.pdf). There is an interesting difference between the NIC and EU ISS reports. The NIC methodology is based on several possible scenarios, while the EU ISS adopted a normative approach, based on a rather optimistic, or best-case belief in the "decompression effect," giving all states of all dimensions greater freedom of maneuver in the international arena.

5 Andersson, "The Transatlantic Relationship." 
the EU), accompanied by middle-tier regional powers such as Turkey, Mexico, Indonesia, Nigeria, etc.

Yet what would be the caveats of this forecast? As far as the economic trend projections are concerned, recent "returns are throwing cold water on the extravagant predictions." ${ }^{\circ 6} \mathrm{We}$ should bear in mind that these countries depend to various extents on Western markets for their exports, be they energy or goods. Moreover, a statement on the "U.S., European, and Japanese share of global income (being) projected to fall from 56 percent today to well under half by 2030 " must be balanced with a general overview of some of the limitations of the BRICS. ${ }^{7}$ They are facing severe internal imbalances and disparities, such as GDP per capita distribution; the stages of development of their internal provinces, regions, and states (in areas like infrastructure, health care, living standards, etc.); and a medium to high potential for internal conflict on ethnic, religious, territorial, social, and democracy-related grounds. In some cases, we are not talking about just a probability, but about ongoing events, such as have been seen in China and Brazil. Speaking of economic growth, Daron Acemoglu and James Robinson argue that China is "unlikely to generate sustained growth unless it undergoes a fundamental political transformation toward inclusive political institutions." " Global military spending dropped in 2012 for the first time since 1998 due to cuts in the West, but there were increases in Russia (16 percent) and China ( 7.8 percent). ${ }^{9}$

There is also the energy dimension to be considered. China, for instance, depends heavily and ever increasingly on imported fossil fuels, and is interested in diversifying and securing its energy routes. Beijing is therefore considering "an energy marriage between China and Iran, (which) could provide a launching point for additional cooperation." ${ }^{, 10}$ But addressing and mitigating these challenges and vulnerabilities involve considerable resources, planning, but most of all time. ${ }^{11}$

And Ruchir Sharma delivers another blow to this multipolar thesis by saying that "the new global economic order will probably look more like the old one than most observers predict. The rest may continue to rise, but they will rise more slowly and unevenly than many experts are anticipating. And precious few will ever reach the income levels of the developed world." 12

6 Ruchir Sharma, "Broken BRICs: Why the Rest Stopped Rising," Foreign Affairs (November/ December 2012): 2-7.

7 "Global Trends 2030: Alternative Worlds."

8 Daron Acemoglu and James Robinson, Why Nations Fail. The Origins of Power, Prosperity and Poverty (London: Profile Books, 2012), 151.

9 SIPRI Yearbook 2013: Armaments, Disarmament and International Security (Stockholm: SIPRI, 2013); available at http://www.sipri.org/yearbook/2013.

10 "China and Iran: Best Chance for a 'Multipolar 'World," Stratfor (12 November 2004); available at www.stratfor.com/analysis/china-and-iran-best-chance-multipolar-world.

11 For a more detailed approach, see Samir Tata, "Recalibrating American Grand Strategy: Softening U.S. Policies Toward Iran in order to Contain China," Parameters 42/43 (Winter/ Spring 2013): 47-58.

12 Sharma, "Broken BRICs." 
Another major setback may be perceived at the coordination level among these powers. "States [forming] the various other poles [of power] are more than willing to sabotage each other. In most cases, even simple bilateral partnerships are impossible."13 The Shanghai Cooperation Organization was meant to address this issue, among others, bringing some of these states to the same table. But diverse (political) cultures, different approaches to internal policies and values, and varying stances toward the essential dimensions of democracy, human rights, and civil liberties represent major (and perhaps even irreducible) differences among these countries.

A different perspective is provided by Niall Ferguson and Zbigniew Brzezinski, who oppose the multipolar vision and instead sound a warning: what if, instead of a multipolar world, there would be just an apolar international system, with states unable to deal with instability, sinking into conflict? The fundamental idea is that in the history of world politics, someone is always the hegemon, or bidding to become one. ${ }^{14}$ The depicted apolar perspective is quite pessimistic, as it would bring about a New Dark Age, with "waning empires and religious fanaticism; endemic plunder and pillage in the world's forgotten regions; of economic stagnation and civilization's retreat into a few fortified enclaves."

History shows that "domination of one sort or another ... has a better chance of preventing the outbreak of war than a system in which no one is really in charge. ... Stability is not the natural order of things. ... Unless some force can, against considerable odds, reinstitute hierarchy..., we will have more fluidity, more equality and therefore more anarchy to look forward to." 16 Or, as Joseph Nye puts it, "war was the constant companion and the crucial instrument of the multipolar balance of power."17

"If America falters," Brzezinski holds, "the world is unlikely to be dominated by a single preeminent successor - not even China." 18 The United States' decline could generate, given a more assertive Chinese nationalism, a phase of acute tension in Asia. This would be characterized by the faltering security of weaker states neighboring major regional powers, which could jeopardize the United States' strategic partnership with Mexico and corrode the management of the global commons. "It is imperative that the U.S. pursue a new, timely strategic vision for its foreign policy," Brzezinski writes, "or start bracing itself for a dangerous slide into global turmoil." ${ }^{19}$ We may well witness an increase in the number or the degree of severity of near-conflicts like the situation on the

13 "China and Iran: Best Chance for a 'Multipolar' World."

14 Niall Ferguson, “A World Without Power," Foreign Policy 143 (July/August 2004): 32-39; available at www.foreignpolicy.com/articles/2004/07/01/a_world_without_power.

15 Ibid., 34.

16 Robert D. Kaplan, "Anarchy and Hegemony," Stratfor (17 April 2013); available at www.stratfor.com/weekly/anarchy-and-hegemony.

17 Joseph S. Nye, "The Future of American Power," in War, Peace and Hegemony in a Globalized World, ed. Chandra Chari (New York: Routledge, 2008), 36-49.

18 Zbigniew Brzezinski, “After America," Foreign Policy (January/February 2012): 26-29; available at http://www.foreignpolicy.com/articles/2012/01/03/after_america.

19 Ibid., 28. 
Korean Peninsula, or over the remote islands in the South (Spratly Islands) and East China Sea (Senkaku/Diaoyu Islands) and who knows what others, some of which could lead to full-scale war.

Richard Haass, on the other hand, envisages another American century, based on several facts: $:^{20}$

- The United States will remain first among unequals in terms of GDP for some time

- The United States has the world's most capable armed forces

- No other major power is in a position to challenge the United States

- The United States has not provoked a direct challenge

- The United States has unique demographics and the potential for renewed economic growth, taking into account its internal advantages: its geography, the balance of its population by age, and the diversity and talents of its society.

"What stands in the way of the next American century is American politics," Haass claims. "Either we resolve our political dysfunction, rethink our foreign policy and restore the foundations of American power," or the alternative will be as dark as suggested by Ferguson and Brzezinski. America's existing security and defense problems (overstretch, war fatigue, etc.) have been emphasized by the crisis-driven austerity on both sides of the Atlantic, which is not happening in the case of the rising powers.

The era of post-unipolarity would have on one hand positive effects, with the possibility of growth for some states and also a certain degree of democratization of development and diversification of the international stage. On the other hand, there could also be negative consequences, such as regional domination of some non-democratic great powers, states of conflict, decreased cooperation, or even global chaos. "If this narrative of American decline is at least partially correct, then the United States will be forced to rebalance its foreign policy to a world that is no longer 'unambiguously unipolar'.,"21 Still, not everything is lost for the United States and its partners, argues G. John Ikenberry: China on the rise should prompt the United States to remember that its leadership of the Western order permits it to mold the environment in which China will make vital strategic choices, and Washington must work to reinforce the rules and institutions establishing that order if it wants to safeguard this leadership. ${ }^{22}$

20 Richard N. Haass, “The Second American Century? It's Already Here," Washington Post (28 April 2013).

21 Nicholas Kitchen, ed., The United States After Unipolarity: Executive Summary, IDEAS reports SR009 (London: London School of Economics and Political Science, 2011); available at http://eprints.lse.ac.uk/43473/1/The\%20United\%20States\%20after\%20unipolarity_executive $\% 20$ summary\%281sero\%29.pdf.

22 G. John Ikenberry, "The Rise of China and the Future of the West," Foreign Affairs 87:1 (January/February 2008); available at www.foreignaffairs.com/articles/63042/g-johnikenberry/the-rise-of-china-and-the-future-of-the-west. 
There are divergent perceptions of the rising powers' approach to the global economy and the international security regimes, whether they "will overcome their own challenges, and more, if they will accept the current world order, or change it." Miles Kahler argues that the rising powers "are moderate reformers that seek greater influence within existing forums and also attempt to safeguard their policy-making autonomy.",23 However, as Sevasti-Eleni Vezirgiannidou notes, "U.S. policy-makers should be aware of the direction in which their current choices are moving the global order; if they do not desire such an order, they should question their strategy towards both rising and minor powers and should show more leadership in the reform of formal institutions." 24

As for the EU, it is one of the best situated actors for the multilateral, multipolar world, even if we consider only its culture of negotiation and diplomacy and its globally recognized soft power aura. The topic of multipolarity is addressed by Alvaro de Vasconcelos from such a perspective - multilateralizing multipolarity: "Europe must be able to define together with other world and regional powers the norms and rules that are needed to drive concerted efforts to stay clear of some future clash of competing unilateralisms. ... The combination of America's active return to multilateralism and the desire for global recognition of other main players opens a window of opportunity for the definition of a common agenda for effective multilateralism and for moving on with a reform of global governance institutions," such as the UN, the framework that is favored by the rising powers.

The rise of several new powers is a noticeable fact; whether they are able to contend with the U.S. on the global scale is debatable. Essential questions arise regarding the consequences of these shifts in power, more exactly about their potential for increased intrastate and interstate conflicts, and on the spillover of regional instability and the potential to create global insecurity. Also, will an economically stronger China or India be able to affirm itself on the international stage on short notice? How long will it take them to transform economic power into military power, and then to project it? With the crisis kicking in, the BRICS may have to delay their moment of defiance of the West. At this point, the transatlantic partnership could demonstrate some of its strong points, consisting in the common values, culture, development level, etc., and the numerous fora that it has built to allow and encourage coordination. The opportunities are there for the transatlantic partners, but essential developments are needed both in the U.S. and in Europe in order to clarify priorities and approaches on global affairs.

\section{U.S. Views and Approaches: A New Balance}

Global evolutions such as the rise of other powers have pushed the U.S. toward a process of setting priorities and conducting an in-depth analysis of its global reach, an intimidating task knowing the "significant fiscal and economic constraints imposed by a

${ }^{23}$ Miles Kahler, "Rising Powers and Global Governance: Negotiating Change in a Resilient Status Quo," International Affairs 89:3 (May 2013): 711-29.

24 Sevasti-Eleni Vezirgiannidou, "The United States and Rising Powers in a Post-hegemonic Global Order," International Affairs 89:3 (May 2013): 635-51. 
federal government debt that has mushroomed to nearly USD 16 trillion or about 100 percent of GDP, and a continuing economic slowdown...."25 After almost thirteen years of engaging in conflict overseas, the U.S. is wary of war, faces serious fiscal problems, and confronts serious questions regarding the challenges to its forecasted waning leadership. The process of updating the United States' grand strategy was postponed due to several factors, as Vezirgiannidou notes: its "long-standing position as a leader of the 'free world' during the Cold War, and then as unrivalled hegemon in the first decade of the post-Cold War geopolitical landscape; also because U.S. decline will happen over a period of time, and therefore some decisions on grand strategy may be delayed accordingly. $" 26$

\section{Uncertain Times}

Uncertainties abound concerning the United States' role in the world, with different views on the best approach to its future strategy. Some authors favor retrenchment, while others stand for further projection of military presence and involvement. So "the real question," Eric Hobsbawm writes, "is whether the historically unprecedented project of global domination by a single state is possible, and whether the admittedly overwhelming military superiority of the U.S. is adequate to establish and ... to maintain it. ${ }^{27}$

According to advocates of retrenchment, such as Barry Posen, the U.S. overstretched its spending in the area of security and defense, based on an "undisciplined, expensive, and bloody strategy, [which] has done untold harm to U.S. national security. ... It is time to abandon the United States' hegemonic strategy and replace it with one of restraint. This would mean giving up on global reform and sticking to protecting narrow national security interests, transforming the military into a smaller force, removing large numbers of U.S. troops from forward bases, creating incentives for allies to provide for their own security.",28

As for relations with the United States' allies, who have reduced their military spending to unprecedented levels (with an average among European NATO member states of only 1.6 percent of GDP), his main point is that the US "should recast its alliances so that other countries shared actual responsibility for their own defense.... U.S. military forces could shrink significantly, both to save money and to send allies the message that it's time they did more for themselves." ${ }^{29}$ Andrew Bacevich promoted a similar

25 Samir Tata, "Recalibrating American Grand Strategy."

26 Sevasti-Eleni Vezirgiannidou, "The United States and Rising Powers in a Post-hegemonic Global Order."

27 Eric Hobsbawm, "War, Peace and Hegemony at the Beginning of the Twenty-First Century," in War, Peace and Hegemony in a Globalized World, ed. Chandra Chari (New York: Routledge, 2008), 15-24.

28 Barry R. Posen, "Pull Back: The Case for a Less Activist Foreign Policy," Foreign Affairs 92:1 (January/February 2013).

29 Ibid. 
approach: letting the Europeans grow from a security and defense point of view. ${ }^{30}$ The U.S. would thus have a more selective presence on the international stage, but could continue "to play a vibrant global role while addressing the ways in which [the U.S.] pursues our objectives. Austerity need not undermine what the United States does." ${ }^{\text {, }}$ Postponing the future grand strategy decision poses a grave danger: "Our posture will be unaffordable, misaligned to emerging challenges, and increasingly dominated by patterns of spending that do not directly support the most relevant forms of national power." 32

In fact, Christopher Layne's "offshore balancing" theory states the U.S. is not compelled to intervene; its stance in 1939-40 was not isolationist, but "a shrewd example of offshore balancing. ... The United States is secure enough from external threat that ... it could choose restraint over intervention.... And it should do so." ${ }^{33}$ Revisited in 2002, this concept is viewed as accepting other players on the global stage, stating that "the United States cannot prevent the rise of new great powers either within (the EU, Germany, and Japan) or outside (China, a resurgent Russia) its sphere of influence. Offshore balancing would also relieve the United States of its burden of managing the security affairs of turbulent regions such as the Persian Gulf/Middle East and Southeast Europe."

Nevertheless, the retrenchment theories lose sight of America's long-standing support for and benefit from globalization. The U.S. still is the world's greatest naval power, which is necessary to protect its commerce and its global interests. On the other hand, to a larger or smaller degree, every major state should be concerned with the safety and security of global sea lines - see, for instance, anti-piracy operations in the Horn of Africa. China, Brazil, Australia, not to mention the EU (and so on) can all invest in cooperation with the U.S. in this area. The international presence in the Indian Ocean around the Horn of Africa fighting piracy represents a good example in this regard.

Another shortcoming of the above mentioned positions is that they do not take into consideration the complex economic, social, and political relations between Europe and the U.S. After all, it may not be in America's national interest to break or weaken its

30 Andrew Bacevich, "Let Europe Be Europe: Why the United States Must Withdraw from NATO," Foreign Policy (March/April 2010); available at www.foreignpolicy.com/articles/ 2010/02/22/let_europe_be_europe.

31 See the very in-depth, detailed, policy-oriented paper by Michael J. Mazarr and the NDU Strategy Study Group, "Discriminate Power: A Strategy for a Sustainable National Security Posture," The Philadelphia Papers 2 (May 2013); available at www.fpri.org/articles/2013/ 05/discriminate-power-strategy-sustainable-national-security-posture.

32 Ibid.

33 Christopher Layne, "From Preponderance to Offshore Balancing: America's Future Grand Strategy," International Security 22:1 (Summer 1997), 86-124.

34 Christopher Layne, "Offshore Balancing Revisited," The Washington Quarterly 25:2 (Spring 2002): 233-248, quote on 245. 
transatlantic links, ${ }^{35}$ losing friends and falling into some sort of an isolationist trap. Europeans fear the United States turning its back on the rest of the world, and the shale gas energy revolution is seen by some as being a further incentive for retrenchment, as it would make the U.S., as President Obama said last March, "less dependent on what's going on in the Middle East. ${ }^{36}$ But, the degree to which the U.S. has been dependent on Middle Eastern oil is only one of the reasons for U.S. interest in that region.

\section{Rebalancing the Pivot - Away from What?}

This is the context in which many eyebrows have been raised across the Asia-Pacific region, but most of all in Europe, since the 2011 Obama Administration "pivot," or strategic turn to Asia. Even though then U.S. Secretary of State Hillary Clinton described the move toward Asia as a pivot with Europe, obviously Europeans have asked a rather simple question, and yet with a not so simple answer: "Away from what?" ${ }^{37}$ A clarification in terms rather than a policy update was issued later by the National Security Council replacing the regrettable "pivot" with "rebalancing," conveying the idea of a continued process of fine-tuning ${ }^{38}$ : "While there's no question that the Asia-Pacific is more important than ever, the phrase signaled that other regions, notably Europe and Africa, were therefore less important." 39

Similarly, the U.S. Secretary of Defense, Chuck Hagel, holds that the United States' rebalancing of its capabilities and resources toward the Asia-Pacific region should not be misinterpreted. "The U.S. has allies, interests, and responsibilities across the globe. The Asia-Pacific rebalance is not a retreat from other regions of the world. Nevertheless, the world is undergoing a time of historic transformation, and Asia is at the epicenter of that change. ${ }^{40}$ The United States' military capabilities and capacities are being reoriented in order to better prepare for future global security challenges.

From a practical perspective, the increased military focus for the U.S. in the AsiaPacific was illustrated by Admiral Jonathan W. Greenert, Chief of Naval Operations, and General James F. Amos, Commandant of the Marine Corps, in the positioning of an initial force of 250 U.S. Marines in the northernmost Australian city of Darwin, which is planned to increase in 2014 up to the level of a Marine Expeditionary Unit (around 1000

35 For instance, the multi-trillion USD transatlantic free-trade agreement "Transatlantic Trade and Investment Partnership (TTIP)," currently under negotiation.

36 Benjamin Alter and Edward Fishman, "The Dark Side Of Energy Independence," The New York Times (28 April 2013).

37 Hillary Clinton, “America's Pacific Century,” Foreign Policy 189 (November 2011): 56-63.

38 See "Looking Forward: U.S. National Security Beyond the Wars," conference organized by the Center for a New American Security, 12 June 2013; details at http://pomed.org/wordpress/ wp-content/uploads/POMED-Notes-CNAS-conference.pdf.

39 James Joyner, "Jones: 'Pivot to Asia' Regrettable Word Choice," New Atlanticist (3 January 2013); available at http://www.atlanticcouncil.org/blogs/new-atlanticist/jones-pivot-to-asiaregretable-word-choice.

40 Chuck Hagel, "The U.S. Approach to Regional Security," speech at the Shangri-La Dialogue, International Institute for Strategic Studies, 1 June 2013. 
strong), the repositioning of U.S. Navy forces in the Pacific region (such as Singapore), and Chinese interest in participation in the next annual "Rim of the Pacific" exercise, RIMPAC $14 .^{41}$

There are several major issues that the rebalancing implies. First, what are the United States' goals in relation to China: containment (according to Beijing) or hedging (according to Washington), meaning simultaneous balancing and engagement. According to Eleni Vezirgiannidou, until now, the U.S. has been rather reticent in engaging China in a constructive way, in the sense of bringing China more into the international system. ${ }^{42}$ Second, on the European side, the reaction was rather wary, showing concern about the future of the transatlantic relationship, which led to a diplomatic tour by U.S. Secretary of State John Kerry of several European capitals in the spring of 2013. So how will the U.S. engage the Europeans in this endeavor? It may present an opportunity for even more transatlantic cooperation, with the EU supporting U.S. efforts, at least based on two EU strong points: economy and politics. ${ }^{43}$ Europeans, or at least some of them, should also be reminding the U.S. that the pivot may present an opportunity for an ever more assertive contender to extend its influence. Along with the rise of China's military, Europe's economy is a key area of concern for the U.S. Thus China and Europe represent "the two areas of the world that are most important in terms of America's long-term economic and political interests" and that also "require a steadfast commitment of American hard power." 44

\section{The Sequester and its Consequences}

But setting goals and elaborating strategies involve assessing available resources, which are no longer at hand at the same levels as a few years previous, when most Western capitalist democracies were visibly trapped in the global economic crisis. The consequences extended from social welfare to wages, and obviously to the security and defense sector as well, which had already been buffeted - at least in most of Europe-by the pre-existing trends of declining budgets. In 2013, it was the United States' turn, with the so-called "budget cap" kicking in on March 1 - an automated mechanism forcing the U.S. public sector to implement cuts in budgets in order to control spiraling deficits. As for the U.S. defense sector, the numbers are astonishing, at least from a European point of view: USD 52 billion in cuts in fiscal year 2013. Eva Gross writes:

41 See "Military Strategy Forum on The Future of Maritime Forces," The Center for Strategic and International Studies, a discussion with Admiral Jonathan W. Greenert, Chief of Naval Operations, and General James F. Amos, Commandant of the Marine Corps, CSIS, Washington DC, 11 July 2013.

42 Sevasti-Eleni Vezirgiannidou, "The United States and Rising Powers in a Post-hegemonic Global Order."

43 See Henriette Rytz, "The Pivot to Asia - Overcoming a Communication Problem," German Institute for International and Security Affairs (SWP) (11 February 2013); available at http://www.swp-berlin.org/en/publications/point-of-view/point-of-view-the-pivot-to-asiaovercoming-a-communication-problem.html.

44 Robert D. Kaplan, “The Virtues of Hard Power,” Stratfor (22 May 2013). 
If sequestration continues (that is, as long as Democrats and Republicans continue to be unable to agree on a budget that includes the required reductions), as much as $\$ 500$ billion will be slashed from the defense budget over the next decade as cuts in projected increases. ... \$489 billion in defense cuts were already scheduled as part of the BCA [Budget Control Act] of August 2011, the compromise made in order to raise the U.S. debt ceiling. The projected sequestration cuts, $\$ 500$ billion over the next decade, will be made in addition to these cuts." $"$ But that is not all: "beginning in FY 2014, the Department of Defense is likely to have to reduce its budgets by at least some $\$ 60$ billion annually throughout the remainder of this decade. ${ }^{46}$

To complicate things even more, military personnel costs (salaries, health care, and other benefits) have nearly doubled since fiscal year 2001, and now consume one-third of the Pentagon's base budget - about USD 180 billion per year. ${ }^{47}$ In addition, in July 2013 came the furlough of thousands of civilian defense employees.

In this difficult and unusual context for the U.S. security and defense establishment, U.S. Secretary of Defense Chuck Hagel directed senior Pentagon officials to re-examine the U.S. military strategy approved last year to see how priorities may need to be adjusted due to the budget cuts. ${ }^{48}$ As such, the Pentagon's announcement of scaling back deployments of combat ships around the world is seen as a worrying sign. The recent cancellation of the deployment of the aircraft carrier USS Truman and its accompanying strike group was a direct consequence of the sequester. For the first time in a decade, the U.S. Navy would only have one carrier strike group on patrol in the Persian Gulf region. $^{49}$

45 Eva Gross, "The American Sequester and Us," European Union Institute for Security Studies, Brief No. 19 (22 April 2013); available at www.iss.europa.eu/publications/detail/article/theamerican-sequester-and-us.

46 Dov S. Zakheim, "The Strategic Implications of a Freefalling U.S. Defense Budget," The American Interest (July-August 2013): 43-51; available at www.the-american-interest.com/ article.cfm?piece $=1431$.

47 U.S. Department of Defense, Overview - United States Department of Defense Fiscal Year 2013 Budget Request (Washington, D.C.: U.S. Department of Defense, 2012), 43; available at http://comptroller.defense.gov/defbudget/fy2013/FY2013_Budget_Request_Overview_Book.p df. See also Lawrence J. Korb, Alex Rothman, and Max Hoffman, "Reforming Military Compensation: Addressing Runaway Personnel Costs Is a National Imperative," Center for American Progress (7 May 2012); available at www.americanprogress.org/issues/security/report/ 2012/05/07/11573/reforming-military-compensation.

48 See David Alexander, "Defense Chief Orders Strategy Review in Response to Budget Cuts," Reuters (18 March 2013); available at http://www.reuters.com/assets/print?aid= USBRE92H0S620130318.

49 Jan Joel Andersson, "The Transatlantic Relationship," Swedish Institute of International Affairs (UI) (2013). See also David Alexander, "Update 1 - Pentagon Delays Carrier's Mideast Deployment over Budget Woes," Reuters (6 February 2013); available at www.reuters.com/ article/2013/02/07/usa-budget-pentagon-idUSL1N0B6ME520130207. 
Dov Zakheim, a former Under-Secretary of Defense, or Comptroller, notes: ${ }^{50}$ "The sequester is a very stupid way for America to manage itself out of its budget problems. Indeed, it may further aggravate them. ... Should the sequester persist, the defense budget would have to be reduced through FY 2021, making for a total of $\$ 1.2$ trillion. Unless the Administration takes major steps to reduce DoD's overhead costs, it will have to cut back on force levels, force posture, deployments and other operations. As then-Secretary of Defense Leon Panetta outlined ... on November 14, 2011, the sequester would lead to the smallest Navy since before 1915, the smallest Army since 1940, and the smallest Air Force ever." 51

The U.S. defense establishment must engage in a strategic overview of the implications of the budget issues, knowing that they terminated some research and development programs and reduced acquisition, military training, exercises, flight hours, etc., thus affecting the readiness of the military and, even more importantly, its long-term preparedness. In times of reassessing priorities and valuing available resources, a temptation might be to go for limited approaches - as has been seen previously, the surgical strike tactic holds appeal during times of budgetary limitations. Still "almost always, a balanced application of military force will be needed to achieve decisive outcomes in war. ... Responsible strategists must confront cost and risk as necessary elements of the game. When two B2 stealth bombers cost more than the entire inventory of main battle tanks in the active Army, something is wrong." 52 Equally it should consider the human dimension, from the decrease in motivation to the likely counterintelligence vulnerabilities. The Snowden case is only the most obviously relevant instance of the potential perils of disgruntled employees' actions.

\section{The Sequester and its Opportunities}

On the other hand, the story of the glass half full could be applied to this topic as well. Some observers feel that the limits imposed by the sequester "may actually be a good thing if they restrain a new burst of expensive American interventionist exuberance.",53 The U.S. may have to find the strength to alter its current way of doing business and look deeper into several opportunities, such as: flexible forces, modular capacities, and forward presence ${ }^{54}$; an ever increasing role for intelligence and special operations forces, which are intended to function below the radar; a different, more integrated approach to research and technology, and the joint development, acquisition, and delivery

50 Principal assistant and adviser to both the Secretary of Defense and the Deputy Secretary of Defense for all budgetary and fiscal matters.

51 Zakheim, "The Strategic Implications of a Freefalling U.S. Defense Budget."

52 Richard D. Hooker, "“The Strange Voyage': A Short Précis on Strategy," Parameters 42 (Winter-Spring 2013): 59-68.

53 Zakheim, "The Strategic Implications of a Freefalling U.S. Defense Budget."

54 "Military Strategy Forum on The Future of Maritime Forces," The Center for Strategic and International Studies, a discussion with Admiral Jonathan W. Greenert, Chief of Naval Operations, and General James F. Amos, Commandant of the Marine Corps, CSIS, Washington D.C., 11 July 2013. 
across the defense services $;{ }^{55}$ and the increased use of unmanned systems in all services, including UAVs (Unmanned Aerial Vehicle) and UCAVs (Unmanned Combat Air Vehicle) for intelligence gathering, surveillance, and even combat missions. On 10 July 2013, the U.S. Navy ran successful tests with the Northrop Grumman UCAV prototype called X-47B, landing itself on a carrier, with no human support, on two out of three attempts. ${ }^{56}$ The development of unmanned technologies points to a shift in the role of the aircraft carrier, ${ }^{57}$ given the need to adapt to anti-access area denial technologies and capabilities ${ }^{58}$ that other powers are developing, not to mention the expanding realm of cyber capabilities (both offensive and defensive). ${ }^{59}$

In this context, the United States will have to work with its allies or simply not be able to pursue its global interests. It definitely is the world's superpower, but will it still be in the future? The Europeans might help; they still do have the economic weight, but they will need to display a more strategic orientation and a greater willingness to share the burden of security.

\section{EU Perceptions and Developments}

The high impact of the large-scale conflicts across its history has determined a European sense of wariness regarding its military spending and culture. It looks like Europe is still afraid of its past; it rejects war to an extent that Council on Foreign Relations President Richard N. Haass described it as a "pronounced anti-military culture." ${ }^{.60}$ This stance was exacerbated by the perception of the absence of any major threat during the post-Cold

55 Claudette Roulo, "Hagel Meets with Troops on Fort Bragg, Discussed Budget," U.S. Department of Defense Website (15 July 2013); available at http://www.defense.gov/news/ newsarticle. $\operatorname{aspx}$ ?id=120456.

56 The onboard parallel computer systems decided the UCAV should land on firm ground on its third attempt. See Sydney J. Freedberg, Jr. and Colin Clark, "Navy, Northrop Score Historic First With (Mostly) Successful X-47B Drone Carrier Landings," Breaking Defense (10 July 2013); available at http://breakingdefense.com/2013/07/10/navy-northrop-score-historic-firstwith-successful-x-47b-drone-carrier-landing/.

57 "The aircraft carrier is in danger of becoming like the battleships it was originally designed to support: big, expensive, vulnerable - and surprisingly irrelevant to the conflicts of the time." Capt. Henry J. Hendrix, USN, “At What Cost a Carrier?", Center for a New American Security (March 2013); available at www.cnas.org/files/documents/publications/CNAS\%20Carrier_ Hendrix_FINAL.pdf.

58 See a document prepared for the United States Army by John Gordon IV and John Matsumura, The Army's Role in Overcoming Anti-Access and Area Denial Challenges (Santa Monica, CA: RAND Corporation, 2013); available at http://www.rand.org/content/dam/rand/pubs/research_ reports/RR200/RR229/RAND_RR229.pdf.

59 Such as the Chinese Dong Feng 21D missile, an anti-ship ballistic missile (ASBM) with a range of approximately $2000 \mathrm{~km}$. See J. Michael Cole, “The DF-21D or 'Carrier Killer': An Instrument of Deception?", The Diplomat (22 April 2013); available at http://thediplomat.com/ flashpoints-blog/2013/04/22/the-df-21d-or-carrier-killer-an-instrument-of-deception.

${ }^{60}$ Richard N. Haass, “The Second American Century? It's Already Here," Washington Post (28 April 2013). 
War era (and the small scale of most conflicts at the time), leading to a postmodern (according to some ${ }^{61}$ ) and idealistic (according to others ${ }^{62}$ ) approach to global affairs.

To its credit, the European Union has shown that it has successfully diminished the probability of war among its member states to the level of "unimaginable." But what is Europe's status on the international stage? Why does defense matter in the post-Cold War era as far as Europe is concerned? Is Europe doomed to remain a "normative power"? Is there a European threat perception?

\section{What Kind of Power?}

The European Union is not a state, but neither is it a classical international organization. Rather, it is a strange object in international law, being identified as a postmodern entity on the international stage. ${ }^{63}$ Due to its disproportionate influence in the international economy, especially when compared to its military capacity, the EU remains rather unclassifiable and, in its role as an international actor, generates numerous debates. ${ }^{64}$ The critics say that its decision-making autonomy is insufficient in order to warrant being granted international actor status.

According to John Mearsheimer, the EU is not a great power, as it does not fulfill the necessary cumulative criteria: it has the resources and the population, but not the military strength. ${ }^{65}$ This consists not only in the sheer numbers and the quality of training of its troops, but also in its lack of an advanced armament industry. To be more specific, the industry exists in Europe, but it is not European - rather, it is fragmented, with each state supporting its national champion. ${ }^{66}$

Other authors have approached the notion, identifying four criteria that the EU must fulfill in order to aspire to an international actor status: ${ }^{67}$

1. The acknowledgment of this status by other actors on the international stage

2. Legal authority to act internationally

61 James A. Caporaso, "The European Union and Forms of State: Westphalian, Regulatory or Post-modern?” Journal of Common Market Studies 34:1 (March 1996): $29-52$.

62 Robert Kagan, Of Paradise and Power: America and Europe in the New World Order (New York: Alfred E. Knopf Editions, 2003).

63

Caporaso, "The European Union and Forms of State."

${ }^{64}$ See Roy H. Ginsberg, "Conceptualizing the European Union as an International Actor: Narrowing the Theoretical Capability-Expectations Gap," Journal of Common Market Studies 37:3 (September 1999): 429-454. See also Franck Petiteville, "L’Union Européenne comme acteur international 'global.' Un agenda de recherche," Revue Internationale et Stratégique 47:3 (2002): 145-57; Franck Petiteville, La politique internationale de l'Union Européenne (Paris: Presses Sciences Po, 2006), 193-231.

65 John J. Mearsheimer, The Tragedy of Great Power Politics (New York: W.W. Norton, 2001).

66 Cristian Iordan, "Le système européen d'acquisition d'armements. Facteur de soutien de la PESD," Romanian Journal of European Affairs 10:4 (December 2010): 87.

67 Joseph Jupille and James A. Caporaso, "States, Agency and Rules: The European Union in Global Environment Politics," in The European Union in the World Community, ed. Carolyn Rhodes (Boulder, CO: Lynne Rienner, 1998), 213-229. 
3. A certain level of decision-making autonomy of the EU (Commission) with respect to its member states ${ }^{68}$

4. Minimal coherence in managing its external relations.

The Lisbon Treaty (2007) addressed these points, bringing about some innovations, however modest, such as:

- A permanent position of President of the European Council (the Belgian Herman Van Rompuy)

- A new High Representative for the Union in Foreign Affairs and Security Policy

- A Vice-President of the Commission (Lady Catherine Ashton)

- The creation of the European External Action Service supporting the High Representative

- The development of a single legal personality for the Union

- Allowing for reinforced cooperation amongst a smaller group of member states in the Common Security and Defense Policy.

Still, obstacles persist to the Union's full strategic existence, and Nicole Gnesotto admits that "one of the biggest ... can be found inside Europe itself, in these old European nations which have invented and then raised national sovereignty as the founding principle of the political order and hesitate, or disincline, to transcend it. ... The political Europe, even more so the military one, remains a sum of nations that are sovereign and are eager to remain so." ${ }^{, 69}$ One should bear in mind the inherent institutional complexity of the EU-its dependence on twenty-eight member states, but equally the conflict between the supranational and the intergovernmental views - that works against any coherent description of the EU as "collective actor." 70 The EU does exert an international influence, be it in international trade, humanitarian aid, or conflict resolution, which leads to it being accepted as an international actor in spite of its incompleteness.

If so, now the question becomes what kind of international actor is the EU. Does it embody soft, civilian, or normative power? In fact, these concepts or visions are interconnected, and based on the EU's non-coercive influence in international relations, supported by "the export or diffusion of norms." soft power, which considers the use of cooperative means in order to convince third parties of your own arguments, exerting an attractive power upon them, deploying resources

68 This represents a debated topic itself, more important in trade and cooperation issues, rather than in security and diplomacy.

69 Nicole Gnesotto, La politique de sécurité et de défense de l'UE. Les cinq premières années (1999 - 2004) (Paris: EU Institute for Security Studies, 2004), 21.

70 Jupille and Caporaso, "States, Agency and Rules," 214.

71 Franck Petiteville, La politique internationale de l'Union Européenne (Paris: Presses Sciences Po, 2006), 229. 
on three levels: culture, political values, and foreign policy. ${ }^{72}$ The concept of civilian power, as defined by Hanns Maull, ${ }^{73}$ involves the acceptance of the necessity of cooperation with others in the pursuit of international objectives; the concentration on nonmilitary, primarily economic, means to secure national goals, with military power left as a residual instrument serving essentially to safeguard other means of international interaction; and a willingness to develop supranational structures to address critical issues of international management. As for the normative power concept, it suggests that the EU is built on norms, and that it can act in a normative way in world politics. So far, so good - the problem is expecting the same from other actors on the world stage. As Ian Manners notes, "Rather than being a contradiction in terms, the ability to define what passes for 'normal' in world politics is, ultimately, the greatest power of all." 74

\section{Limitations}

The theory of Europe as a normative power proposes a high-end, intellectual debate, but sadly there is no Plan B. What if you cannot convince or negotiate your way out of a problematic situation?

Not willing to devote serious thought and resources to its security and defense, Europe appears to be thinking that it can simply remain aloof from it all, focusing on the pressing issues related to the prolonged economic crisis, in some sort of ongoing freeride attitude. Thus, European states have ended up paying only 20 percent of the overall NATO bill, and even though EU member states cover a quarter of global military spending, only a fraction goes towards the CSDP, which lacks in capabilities and experts, but most of all in (strategic) coherence. The EU defense budget has shrunk from EUR 251 billion to EUR 194 billion during the last decade. ${ }^{75}$ The ESDP is not driven by considerations of efficiency; it is reactive, "event-driven." It took some time for Europeans to intervene in theatres like Kosovo, the Horn of Africa, Libya, and Mali.

The EU is still trying to find its strategic path(s), and has initiated a joint foresight capacity - the European Strategy and Policy Analysis System, or ESPAS - that "assesses long-term global trends to help them strengthen policy planning. ... What is often meant by [strategy] is a clear objective, an action plan, a roadmap, a compass, a sense of direction, ... overcoming muddling through and purely reactive behavior." 76

72 Joseph Nye, Soft Power: The Means to Success in World Politics (New York: PublicAffairs, 2004), 6 .

73 H.W. Maull, "Germany and Japan: The New Civilian Powers," Foreign Affairs 69:5 (1990): 92-93. See also Karen Smith, "The End of Civilian Power EU: A Welcome Demise or Cause for Concern?", The International Spectator 35:2 (April-June 2000): 11-28.

74 Ian Manners, "Normative Power Europe: A Contradiction in Terms?", JCMS 40:2 (2002): 252-53.

75 See Anna Barcikowska, Securing the Future of European Defense (Paris: EU Institute for Security Studies, July 2013).

76 Antonio Missiroli, "Strategic Foresight and the EU," Brief Issue 13 (Paris: EU Institute for Security Studies, 2013); available at http://www.iss.europa.eu/uploads/media/Brief_13.pdf. 
There is a fair amount of risk that the EU will lose relevance in the realm of security - if it ever had it in the first place. The member states may be underestimating the decline of their role, at least in international affairs. The 2011 conflict in Libya showed the limitations of the European states and the EU itself, and of the current security and defense mechanisms, as Europe had difficulties in projecting power (airlift, fuel, logistics). Libya should have been the wake-up call, but then came Mali, where France/the EU were forced to ask for assistance in another medium-scale military operation in the European vicinity.

Listing the ongoing problems, a EUISS document ${ }^{77}$ mentions excessive resources dedicated to personnel and land-based facilities; force structures encompassing an excess of certain military capabilities while neglecting other capability shortfalls; the EU defense equipment market's high degree of fragmentation; resources devoted to research and development remain limited, and are even shrinking; and cross-national coordination, cooperation, and integration - from research to procurement, from logistics to military force and defense planning. To these might be added the fact that EU policy is spread across distinct and often separate agencies and institutions, with tools that are hard to bring together to generate the desired coherence and synergies, and where none has an exclusively military competence.

\section{The Rebalance and Europe}

Given the challenges outlined above, is Europe doomed to remain only a "normative power"? In a previous paper, the question asked was if Europe is facing a security crisis at a strategic level, and what would happen if the United States were not able or willing to intervene in support of Europe. ${ }^{78}$ The U.S. is already more selective in engaging in wars - it pursued a limited intervention in Libya, even less in Mali, and almost none at all in Syria. What if this is precisely what the rebalance is about?

When U.S. decision makers started addressing the Asia pivot, Europeans got nervous. First of all, we have to take into consideration that the "pivot" (or "rebalancing") has multiple dimensions: trade, cultural, and military. From Europe's perspective, for the EU to have a say about events in its own backyard, the European security and defense capacity does not need to be an offensive one along the lines of the U.S. military concept. It would be far too costly, it would not fit the European mindset, and it would not be politically acceptable. However, a proper modular expeditionary force must be built according to military criteria (not those of political expediency), having as its goal the management of both humanitarian (Libya) and military (Mali) crises. But this demands something that is in extremely short supply in Europe - consensus, or political

77 Antonio Missiroli, ed., Enabling the Future European Military Capabilities 2013-2025: Challenges and Avenues, Report No. 16 (Paris: EU Institute for Security Studies, May 2013); available at http://www.iss.europa.eu/uploads/media/Report_16.pdf.

78 Cristian Iordan, "Defending Europe," Per Concordiam 3:2 (2012): 46-53; available at www.marshallcenter.org/mcpublicweb/MCDocs/files/College/F_Publications/perConcordium/ pcv3n2eng.pdf. 
will, whichever you prefer. It is not enough to address the value of the transatlantic community and partnership only in speech. As poker players say, Europe needs to put its money where its mouth is. Children hear this often: if you value something, you take care of it. "Barack Obama does not look at the world in traditional 'Atlanticist' ways. Nor, increasingly, do other Americans," Michael Cox cautions. "The old certainties, and in part the old diplomacy, that held the Western alliance together no longer pertain; and the sooner Europeans recognize this, the sooner they will be able to forge a new role for themselves in a fast changing world. The answer lies in their-and nobody else'shands." 79

Nevertheless, increasing defense spending in the Asia-Pacific, squabbles over the islands in East and South China Sea (territorial disputes between China and the Philippines, Japan, and others), and proliferation of nuclear technologies should thus be of equal interest to all member states of the EU. But the EU's approach, compared to that of the U.S., focuses mainly on trade and development issues, as shown in the trip taken by Catherine Ashton in May 2012, with the largest ever delegation of EU officials to an EU-ASEAN ministerial dialogue, which promised deeper institutional ties on everything from counter-terrorism to trade, and even more eloquently in a EU official saying: "The U.S. will be an Asian power. We will be an Asian partner." And "there are a number of areas where the EU could potentially play a useful role in East Asian security": common cross-border challenges, conflict mediation, and the potential military role. ${ }^{81}$

\section{Reasons for (Moderate) Optimism?}

But maybe not everything is lost. For a balanced approach, one should admit that the EU has the edge in civilian and diplomatic crisis management (with 57,000 diplomatic personnel around the world), which contributes to its competitive advantage. After long years of work, Europe has managed to mediate a Serbia-Kosovo agreement through its diplomatic capacities. It takes a while for the states to understand, to get involved, as the "small steps policy" bore witness throughout the history of the construction of the EU. Another relevant moment is scheduled to begin in December 2013, with the EU Summit dedicated to security and defense - the first such summit since 1999-and preparations for the revision of the European Security Strategy. The European strategic reflection is visible in two informal reflection groups, known as "European Global Strategy" and the "Future of Europe Group."

The first initiative, "Towards a European Global Strategy: Securing European Influence in a Changing World," was achieved via a think-tank process, reuniting representa-

79 Michael Cox, "No Longer Inevitable? The Transatlantic Relationship from Bush to Obama," in Europe in an Asian Century: Visions for Europe, LSE IDEAS, ed. Nicholas Kitchen (London: The London School of Economics and Political Science, 2012), 22-28.

80

Laurence Norman, "EU Looks to its Own Asia Pivot," Wall Street Journal (3 May 2012).

81 Daniel Keohane, "The EU's Role in East Asian Security," in Look East, Act East: Transatlantic Agendas in the Asia Pacific, ed. Patryk Pawlak (Paris: EU Institute for Security Studies, December 2012), 45-50; available at http://www.iss.europa.eu/uploads/media/Final_ Report_13LEAE.pdf. 
tives of several member states (Italy, Poland, Spain, and Sweden), and was meant to provide inspiration and input for the formulation of a future European Global Strategy by the EU institutions and all the member states, and with the High Representative and the European External Action Service playing a central role. It holds that an agreement on EU strategic objectives should increase its readiness for action, which would gain in effectiveness based on the ability to deploy standardized and interoperable civilian and military capabilities, such as the Battlegroups. ${ }^{82}$ Changes are necessary in how EU missions are financed, in order to facilitate deployment and implement fairer burden-sharing among member states, with pooling and sharing among groups of member states applied to the whole of defense spending (research, procurement, maintenance and logistics, military education) ${ }^{83}$ Equally important are deepening of the EU's defense market and coordinated investment in dual-use technologies.

A second interesting development is the "Future of Europe Group," which reunites the foreign ministers of Austria, Belgium, Denmark, France, Italy, Germany, Luxembourg, the Netherlands, Poland, Portugal, and Spain. In the foreign dimension, it has identified several issues and is providing bold proposals:

- Improving the overall functioning of the EU, with adjustments in institutional functioning (Commission, Foreign Affairs Council)

- A revision of the EEAS, HR/VP responsible for key external action areas

- More majority decisions in the CFSP

- Joint representation in international organizations

- The development of a European Defense Policy, with a single market for armament projects, and (for some members, at least) with a European army - an ambition beyond pooling and sharing.

Both initiatives, even though they are informal, represent positive developments in the past year, marking a new approach to the strategic challenges Europe is facing, and bringing constructive critiques to bear in order to address these challenges. They also indicate that Europe has to make some choices and changes, some of which may be painful in terms of economy or sovereignty. Patching the old coat may no longer be enough; it's time for a new one. European states may also need to consider giving up on some of their major ambitions, which will be a very difficult thing for their constituencies to accept - for example, the European welfare model, based on a balance of population leaning toward the young and active segment. Given that the statistics show that the population is getting older, and not only in Europe, but in the "Western"/developed states, this cherished European model of the welfare state may no longer be sustainable.

82 The EU has issued a set of "Battlegroups Standards and Criteria," which have been encouraged to rely on existing NATO standards, in order to avoid duplication and promote interoperability.

83 For instance, the Netherlands has given up on their entire contingent of tanks, and they share naval training with Belgium. 
Another element that will have to be addressed in the future is related to the relationship between CSDP and NATO, which currently is not entirely functional. For a number of reasons, which include resource issues and then basic common sense, there has to be a clarification and a division of labor, in spite of the two groups' different member states, visions, and strategic cultures and so on. It is significant, though, that a number of European countries, members of both NATO and the EU, do not consider the relationship between the two as problematic, but rather as mutually supportive. Such are the cases of Poland and Romania, which for years have stated very clearly their commitment to both the transatlantic partnership and to the European project, being involved in both organizations in security-related areas. Poland represents an interesting case. It is very active in the area of security and defense and is actively engaged in the NATO missile defense project, but is also involved in the European Battlegroups (Poland, France, Germany) and is represented in the European informal reflection groups.

Not least, a very important factor is public support in Europe - precisely from the younger generations, who are assertively pro-European, and who have put their faith in the role Europe can and should play in the world. The values that the EU is based upon and continues to support, similar to NATO, are universal: democracy; respect for human rights, individual liberties, and minorities; good governance; peaceful resolution of conflicts; economic integration; and free trade. The EU is known worldwide for supporting these realities and concepts. In fact, the EU itself represents the best example for successfully putting into practice the abovementioned values. And yet, Europe has had few means of enforcing its beliefs and values, and each instance when it has done so has come with caveats: the Western Balkans, Horn of Africa (anti-piracy operations), Libya, Mali, etc. After twenty years of efforts, the last two represent important landmarks for the state of European ambitions, ${ }^{84}$ revealing that Europeans are still not able to manage a crisis in their neighborhood on their own, a situation aggravated by the economic crisis, the need to rationalize expenditure, and also by the U.S. pivot toward the Pacific. Given an increase in coherence and effectiveness, the CSDP could represent Europe's means of putting into practice what it stands for when its diplomatic and crisis management negotiation skills run out or are irrelevant. Using the CSDP not necessarily as a power projection tool, à l'américaine, but as the extension of international law, which it highly esteems, "would greatly strengthen the EU's political standing at home and abroad." 85 Moreover, the power of normative Europe should be addressed and studied as events unfold in East Asia, as Europe may selectively apply its international aura in delicate, diplomatic negotiations.

${ }^{84}$ Luis Simón, interview with Jolyon Howorth, European Geostrategy (4 September 2012); available at http://europeangeostrategy.ideasoneurope.eu/2012/09/04/interview-with-jolyonhoworth.

85 Mary Kaldor, "A European Conception of Security," in Europe in an Asian Century: Visions for Europe, LSE IDEAS, ed. Nicholas Kitchen (London: The London School of Economics and Political Science, 2012). 


\section{Trends, Risks, Challenges}

Several authors have recently addressed the differences between Americans and Europeans on major strategic and international issues. In 2002, Robert Kagan's "Mars and Venus" theory described how the Hobbesian U.S. was asserting its power in pursuit of its objectives, while Kantian Europeans, lacking such power, favored a rule-based system. Then, Robert Cooper, in his essay on the need for a new "liberal imperialism," warned Europeans not to overlook the importance of military power in a world that still required it. Cooper identified a postmodern approach at the European level, which had given up on power politics; but Europe could not let down its guard in dealing with the rest of the world, which had not.

The circumstances of the 2003 Iraq war strained transatlantic relations and underscored the differences in approach and policy that had come into stark relief after President George W. Bush took office. The election of Barack Obama then seemed to guide the United States and Europe back into alignment. But the most serious threat to the Western alliance was not foreseen, meaning the crisis of governance afflicting both sides of the Atlantic: the United States - political dysfunction, while the EU is struggling to bring financial stability. ${ }^{86}$

\section{The Declension Theories}

Hence talk of the fading West and the declining Western alliance started anew, based on the change in generations and the change in the global arrangement of power - namely, the rise of multiple non-Western nations/powers. Michael Kimmage wrote, "Within the Obama administration, the West is not an entity to be rejected or transcended. It does not matter much. Obama and his generation were not educated to believe in the West. The decline of the West has encouraged Obama in his 'pivot' to Asia. Europe happens to find itself, for the first time in centuries, in a more provincial place. The Atlantic is ceding its stature to the Pacific." ${ }^{, 7}$ Under such conditions, as Simon Serfaty points out, the combination of U.S. austerity and European detachment can ensue in "a form of neoisolationism that neither the West nor the rest can afford." 88

But when addressing Europe and transatlantic issues, an essential observation must be made: NATO and the EU share a majority of members (22 out of 28 members in each organization). We should remember the essential internal political choices (Norway's twofold rejection of EU accession and yet its active participation in NATO); limitations, such as neutrality (Austria); and sometimes plain rivalry (Turkey and Greece). Europe is very far from being a bloc, even though, when considered together, the cold numbers are

86 Charles A. Kupchan, “A Still-Strong Alliance,” Policy Review 172 (30 March 2012); available at http://www.hoover.org/publications/policy-review/article/111956.

87 Michael Kimmage, "The Decline of the West: An American Story," Transatlantic Academy Paper Series (4 June 2013); available at www.transatlanticacademy.org/publications/declinewest-american-story.

88 Simon Serfaty, "The Folly of Forgetting the West," Policy Review 174 (1 August 2012). 
impressive. The challenge is there because the combined numbers speak so loudly. Transforming the EU- the world's largest economy, with the world's second-highest defense budget after the United States - a genuine soft power, into a relevant player and partner on the new international stage is a tremendous challenge. For now, even though weaker than some of its prominent member states, the EU is far from falling into irrelevance on the international stage, due to its inner, proven strengths.

\title{
Gaps in NATO's Armor?
}

As for the transatlantic alliance, its strength is visible in the fact that it has survived the threat it was based upon. Think of Lord Ismay's famous saying: U.S. in, Germany down, and Russians out! All jokes aside, the primary definition of this alliance still is politicalmilitary, assuring the security of almost one billion people living in some of the world's most advanced capitalist democracies.

But there are several points where NATO is and will be challenged. The first is in the context of the diminished capabilities of its militaries. The shortcomings of the Europeans surfaced in the Libya episode, determining powerful voices such as (then) Secretary of Defense Gates to bluntly state the perspectives of a "dim, if not dismal" future for the Alliance (2011). As Heather Conley and Maren Leed write,

\begin{abstract}
Simply put, NATO's future rests on the prospects for European defense spending and European political willingness to use the capabilities in which they invest. European military capabilities are fragmented, duplicative, and more expensive than they need to be. According to NATO, the 26 European allies combined spent $\$ 282$ billion on defense budgets in 2011 (or about 27.2 percent of the NATO total), while the United States spent $\$ 731$ billion (70.5 percent). Washington policymakers are now arguing that NATO must quickly move toward a $50 / 50$ rather than a $75 / 25$ alliance. ${ }^{89}$
\end{abstract}

If the current trends of demilitarization and illogical and ineffective choices continue, with European military capabilities shrinking to meaninglessness, "Europe contemplates losing geopolitical relevance." 90 The Europeans have already shown twice in two years that they are unable to act without U.S. military support. The U.S. has nevertheless maintained a relatively reduced presence, "leading from behind," appreciating the fact that (some) of its European allies are willing and able to act when needed. But for how long? Will France be able in several years to sustain another Mali, knowing that the full impact of continuing defense reductions has not been felt yet? Hence an American perception that (small) European countries are security consumers, not providers, even in a NATO context - that Europeans focus on welfare, instead of security, and when needed, it is the United States that sacrifices.

Moreover, there have been voices asking about NATO's future after Afghanistan, fearing that there would not be a security project to bring the members together. But there are plenty: emerging security challenges, defense austerity in NATO nations, and

\footnotetext{
89 Heather A. Conley and Maren Leed, "NATO in the Land of Pretend," Center for Strategic and International Studies (26 June 2013); available at http://csis.org/print/44880.

90 See Kupchan, "A Still-Strong Alliance."
} 
Smart Defense represent profound topics for NATO concern, on which the military and civilian staff can reflect without smoke and fireworks. The project is the same as when the Alliance was launched - our better integration and interoperability, better planning, and more preparedness in order to face common risks, threats, and challenges.

NATO Secretary-General Anders Fogh Rasmussen expressed his fear that leaving Afghanistan may provide an excuse for further budget cuts. On the contrary, these are some of the valuable lessons of the more than a decade-long presence in Afghanistan, which - as Secretary-General Rasmussen declared - need to be preserved and enhanced as NATO moves from a combat operation to a training mission in Afghanistan, beginning in 2015. The initiative bears the name Connected Forces Initiative (CFI), and aims to maintain NATO's readiness and combat effectiveness through expanded education and training, increased exercises, and better use of technology. ${ }^{91}$

Second, "Smart Defense," defined by Rasmussen as a "renewed culture of cooperation, ${ }^{, 92}$ encourages the Allies to cooperate in developing, acquiring, and maintaining military capabilities to meet current security problems in accordance with the new NATO strategic concept. The approach involves pooling and sharing resources (also addressed in the EU related section), setting priorities, and coordinating efforts better. The other Allies must reduce the transatlantic gap by equipping themselves with capabilities that are deemed to be critical, deployable, and sustainable. ${ }^{93}$ But "'Smart Defense' has to become much more than another 'bumper sticker' slogan in order to ensure real change in developing and sharing the critical capabilities needed to address threats," 94 for which the essential element is political determination. At this point, a successful example is the Strategic Airlift Capability, which reunites ten member and two partner nations, hosted in Hungary and operating Boeing $\mathrm{C} 17 \mathrm{~s}$.

Finally, there are two interrelated issues: a successful balance and articulation between the EU and NATO (including by clarifying the CSDP-NATO connection on capabilities, planning, deployment, etc.) could represent an advantage also in dealing with the vicinity (Northern Africa, Turkey, Caucasus, Belarus, Ukraine) and in engaging Russia. These will continue to represent topics high on NATO's agenda, on several topics of common interest: geographical proximity, managing emerging security challenges, missile defense, energy security, etc. In this regard, France and Turkey play essential roles. Their flexibility and desire to overcome past differences can make a difference.

91 The Connected Forces Initiative, NATO website, at www.nato.int/cps/en/SID-3A1489DD47A3C221/natolive/topics_98527.htm.

92 NATO press conference by NATO Secretary-General Anders Fogh Rasmussen after the first session of the North Atlantic Council in Heads of State and Government format, 20 May 2012; available at www.nato.int/cps/en/natolive/opinions_87598.htm.

93 "Smart Defence," NATO website, available at www.nato.int/docu/review/Topics/EN/SmartDefence.htm.

94 Martynas Zapolskis, "NATO'S Strategic Challenges: The Alliance Strives to Maintain Integrity in an Uncertain Global Environment," Per Concordiam 4:2 (2013): 24-29. 


\section{Opportunities}

An effort to reinforce the solidity of the partnership, from an economic perspective, started on 14 June 2013, when the European Commission, on behalf of the EU, initiated talks with the United States on the Transatlantic Trade and Investment Partnership (TTIP), a proposed free trade area agreement between the United States and the European Union. Even though each side is trying, obviously, to protect certain sectors of its economy, it still is the biggest bilateral trade deal ever negotiated, and potentially the largest regional free-trade agreement in history. It could result in millions of Euros of savings to companies and could create hundreds of thousands of jobs, covering "more than 40 percent of world GDP, and accounting for large shares of world trade and foreign direct investment. The TTIP would eliminate all trade tariffs and reduce non-tariff barriers, including in agriculture; expand market access in services trade; closer regulatory harmonization; strengthen intellectual-property protection; restrict subsidies to state-owned enterprises; and more." 95 This will only lead to more interdependence, to both economic and political integration. Nobody can allow this to unravel, based on the profound economic and social benefits. ${ }^{96}$

Another area where the transatlantic dialogue is crucial in order to have a coherent and efficient approach is critical infrastructure protection. Most such infrastructures in NATO and EU countries are under private ownership or administration; of even greater importance is the fact that both military and civilians use, most of the time, the same fiber optic cables, energy grids, and water supplies. At the EU level, the process of identifying and designating national and European critical infrastructures is a fairly advanced, and member states are working with the public and private sectors on a set of protective measures. Now think of securing the information systems and networks of the twentyeight NATO member states, from the U.S. to Albania. That is quite a security project, I would argue.

For NATO to remain the primary vehicle of transatlantic cooperation, it must see its role deepen and become relevant in areas such as emerging security challenges, including cyber security, ${ }^{97}$ turning it into an area of cooperative security and defense. Creating common standards has proved its utility in armaments; it may prove useful in this area as well. Cyber could, among others, continue the link between the two sides of the Atlantic, covering its several sub-domains - crime, espionage, warfare-that are of greater or lesser concern for the Atlantic community (member states and international organizations). It becomes relevant when states and international organizations alike are faced

95 Michael J. Boskin, "Transatlantic Trade Goes Global," Project Syndicate (16 July 2013); available at http://www.project-syndicate.org/commentary/the-global-implcations-of-eu-usfreet-trade-by-michael-boskin\#k0EPsyF5Mrk0ALsZ.99.

96 See Thomas Ilgen, "The Future of the Transatlantic Partnership," in Hard Power, Soft Power and the Future of Transatlantic Relations, ed. Thomas Ilgen (Farnham, Surrey: Ashgate, 2006), 195.

97 "Cyberwar: War in the Fifth Domain," The Economist (1 July 2010); available at http://www.economist.com/node/16478792. 
with an ever increasing number of attempts on the part of various entities-whether state-sponsored or not - to gain illegal access to sensitive data of various kinds. Cooperation in the area of cyber security and defense thus turns into an opportunity for creating new "alliances" (at both the internal and international level), but also building on previous efforts and experience, deepening existing, functioning security mechanisms.

This may lead to two possible scenarios:

1. The states will go for the option of double-speak, stating that they want to work together, while, in fact, sinking into isolationism

2. They overcome their survival/isolationist reflexes and build a real security community.

Collaboration through sharing threat data, including through a public-private partnership, ${ }^{98}$ could be one way of turning our collaborative culture and open societies into a competitive advantage, allowing us to mitigate, stop, and (even more important) prevent information security breaches and attacks.

The twenty-first century transatlantic relationship may not necessarily mean having U.S. tanks or A10 Thunderbolts based in Europe, but rather the two sides of the Atlantic managing the transition to a world in which the West is no longer in charge while still working together on new and complex issues. We can find strength in numbers and the way we function; transatlantic solidarity is still rooted in our common interests and values. James Howcroft writes, "Military partnerships today are more important than ever before. America's current national strategy, coupled with global fiscal and political problems, makes it unlikely for Americans to deploy unilaterally to address the security challenges of the 21 st century." ${ }^{" 99}$ It is a moment in which subtler areas of cooperation could see a boost (if that has not already happened), such as intelligence and cyber security. With this in mind, there is something more that transatlantic leaders have to consider: how best to engage the populations on the topic of today's and tomorrow's security challenges and threats.

Both parties have some things to learn from and must support each other, as the conditions of twenty-first century geopolitics make it impossible for any of them to act alone on the world stage. The European soft power approach to international affairs can provide useful insights and support to U.S. interests. "On many of today's key issuesinternational financial stability, drug trafficking, the spread of diseases and especially terrorism - military power alone simply cannot produce success, and its use can sometimes be counterproductive. Instead, the U.S. must cooperate with Europe and others to

98 See Wade Williamson, “Combating Emerging Threats Through Security Collaboration," Security Week (17 December 2012); available at www.securityweek.com/combating-emergingthreats-through-security-collaboration.

99 James Howcroft, "Things Americans Need to Know: How to Be Better Partners," Small Wars Journal (25 June 2013); available at http://smallwarsjournal.com/print/14148. 
address these shared threats and challenges." 100 In fact, in a recent article, Gen. David Petraeus praised the value of (foreign aid as) soft power, alongside its armed forces, improving national security and advancing U.S. global interests. ${ }^{101}$ This soft power dimension of the EU has proved its value through its significant contribution to achieving peace and maintaining stability in the Balkans, and it has the potential to be a sustainable, long-term solution. The prospects for Turkey to join the EU and also the special trade agreements with Northern Africa may represent useful instruments to address the issue of stability in Europe's neighborhood. Questions thus arise as to the possibility of exporting the European model in the world: can peace, stability, and development take root elsewhere, under different conditions? As Joseph Nye puts it, "For a security partnership to work, it may be necessary for the U.S. to rediscover the value of 'soft power' and for Europeans to develop 'hard' power resources of their own."102

Even though it looks like it is very difficult to strike the right balance, I would submit that the transatlantic alliance still is "inevitable." ${ }^{103}$ But there is a strong need for political will across the board, in parliaments and governments alike, on both sides of the Atlantic, not least when dealing with budget deficits, and even more so in explaining to their constituencies why it is important to invest in security and defense and outlining the considerable costs of failure. In Europe, at least, this was not and still is not a prominent issue in public debate. Things have to change for us to remain viable partners engaged in an efficient and effective relationship.

\section{Conclusions}

Uncertainty describes the international system today, perhaps more than ever. We have witnessed a rise of several other powers, but they are all affected - to various extentsby the financial and economic crisis, or internal problems and imbalances, all of which stymie their rise to the status of "great powers." Therefore, the theories of multipolarity or polycentricity (depending on the perspective) still are debatable topics.

The United States has seen its role and power challenged and diminished due to its internal economic problems, resulting even in declining defense budgets and a reduction in its military capability. Still, even facing the current problems, opportunities for the U.S. to regain the lost ground are at hand: "viable alliances and partnerships, economic adaptability, flexibility and innovation, significant soft power attractiveness in the culture and ideology of an open society," 104 prospects of energy independence and the re-

${ }^{100}$ Joseph Nye, "Soft Power and European-American Affairs," in Hard Power, Soft Power and the Future of Transatlantic Relations, ed. Thomas Ilgen (Farnham, Surrey: Ashgate, 2006), 25-35.

${ }^{101}$ Gen. David Petraeus and Michael O'Hanlon, “Fund-Don't Cut-U.S. Soft Power," Politico (30 April 2013); available at http://www.politico.com/story/2013/04/david-petraeus-defensediplomacy-soft-power-90781.html\#ixzz2a8Y1fbSt.

102 Nye, "Soft Power and European-American Affairs."

${ }^{103}$ Vittorio Parsi, The Inevitable Alliance: Europe and the United States Beyond Iraq (London: Palgrave Macmillan, 2006).

${ }^{104}$ Joseph Nye, The Future of Power (New York: Public Affairs, 2011). 
sulting economic growth, the highest-ranking universities in the world, and a general sense of purpose. Added to this, the projections of GDP cannot be the only argument for the rise of other states as potential great powers. The key, Nye argues, resides in the combination of the hard power of coercion and payment with the soft power of persuasion and attraction into successful strategies - a combination that can be defined as smart power.

Europe has been the home of the world's great powers for centuries, as well as their battleground. We have overcome this sad and bloody episode of our history, achieving the longest period of peace and stability in European history, becoming a global model and supporter of democracy, human rights, rule of law, social welfare, health care, and peaceful resolution of conflicts. Peace has paid its dividends. But this flourishing is in no small part due to the transatlantic relationship and the security it has assured.

Nevertheless, Europe should pay more attention to the "other" means that can be used to address our sometimes volatile neighborhood. We keep seeing how European military power is declining - in two years, we have witness two such disheartening examples, in Libya and Mali. Why is it important to address this? In the absence of sufficient military capabilities, Europe could find itself in a weak spot, vulnerable, unable to deal with military crises in its neighborhood, at least in the medium term.

This is not to say that Europe or the U.S. or anyone else should adopt a belligerent attitude. Far from it. I am not necessarily offering a defense of the doctrine of liberal imperialism, but basic common sense should tell us all that armies are not supposed to shovel the snow and clear the roads in winter. The military should not be a social welfare organization, but rather a strong, mobile, connected, interoperable force, able to move and act swiftly for the reasons (humanitarian or other) that the UN would sanction, to deal with twenty-first century threats having the potential to cause major disruptions to our societies.

Is the transatlantic vehicle still working? NATO is preparing for its withdrawal from Afghanistan, and not necessarily with an ensuing peace dividend. Rather, it too is facing a "do more with less" logic, the inevitable topic of security and defense budget cuts. The attention given to emerging security challenges will increase. Cyber security could be among the factors that will impose changes on national security and defense strategies, and NATO's strategic vision and the Atlantic partnership, as a possible area for (among others) deepening cooperation among "Western" democracies.

As for the way ahead, adjustments have to be made on both sides, depending on political courage and vision. Europe must become aware of its strong points, to find and renew its commitment to further its project, to become more responsible and credible in global foreign policy and regional security and defense. Europe must also confront its demographic challenge, with declining and aging populations, ${ }^{105}$ which will exert an ever increasing pressure on the welfare system. An interesting process is underway in a European Commission initiative aimed at strengthening the European defense industry,

${ }^{105}$ See Matthew Rhodes, "U.S. perspectives on NATO," in Understanding NATO in the $21^{\text {st }}$ Century, ed. Graeme P. Herd and John Kreindler (New York: Routledge, 2013), 33-49. 
with a view to creating a single European defense market. In order to become a real partner, the old, familiar concept of "burden-sharing" has to once again be taken into consideration by the Europeans, but seriously this time. This involves a shift in European thinking, in the attention given to security and defense, in order to identify proper sources of financing, draft realistic defense budgets, and develop more relevant modes of defense cooperation.

The U.S. defense establishment has to attentively and responsibly address the national deficit and its implications on both internal dimensions (e.g., investing in infrastructure) but also on the instruments of power projection (hard power, such as military and intelligence capabilities, but also soft power, such as alliances, foreign aid, diplomacy, and culture). "The United States needs to see Europe as part of a global strategy, rather than a relic of the past, to be shed as America moves on to an Asian strategy. ... The United States and Europe should now be leading the way in defining an international order for the future - one that fully enfranchises emerging regions and powers while enlisting their support in reinforcing the core democratic values and liberal international economic order that have brought us this far. It can be done, but - as in 2002 it means overcoming our tendencies toward playing the roles of Mars and Venus, and instead putting our efforts together in common purpose." $" 106$

In summary, we are all living in times of change, of uncertainty, of strategic shifts. But the choices we make now will shape our future. The so-called "decline of the West" may not be that close. What if, after all, the biggest challenge for Europeans and Americans is to continue what we started together, to pursue and deepen our partnership? The reasons are numerous: we should not underestimate the power of our common values, trust, civilization and, yes, our common goals. Together we represent the first economic, military and - not least—-soft powers of the world.

There is no viable alternative to the transatlantic partnership. It has demonstrated its benefits over the years, and it can definitely do so in the coming years, whether NATO, on a political and military level, or (hopefully soon) TTIP ${ }^{107}$ on the economic and trade level. Moreover, in a multipolar, polycentric, multimodal, or even multiplex world, both the U.S. and Europe would, by definition, lose a part of their influence on world affairs, and as a consequence they would find themselves in a position of increased dependence on each other, mutually reinforcing, based on their shared history, values, and-hopefully-vision, interests, and trust, addressing challenges that we cannot deal with separately, such as climate change, changes in global governance, cyber (in)security, and so on. Even though it may be troubled from time to time, our relationship must continue.

${ }^{106}$ Kurt Volker, "Reaffirming Transatlantic Unity," Policy Review 172 (30 March 2012); available at http://www.hoover.org/publications/policy-review/article/112246.

${ }^{107}$ The Transatlantic Trade and Investment Partnership (TTIP) represents a deepened and more integrated relationship between the world's two largest economies - the U.S. and the EU-and offers considerable potential benefits to consumers and companies alike. See www.acus.org/ content/ttip. 


\section{Bibliography}

Acemoglu, Daron, and James Robinson. Why Nations Fail. The Origins of Power, Prosperity and Poverty. London: Profile Books, 2012.

Alexander, David. Defense Chief Orders Strategy Review in Response to Budget Cuts. Reuters, 2013.

Alexander, David. Update 1 - Pentagon Delays Carrier's Mideast Deployment over Budget Woes. Reuters, 2013.

Alter, Benjamin, and Edward Fishman. "The Dark Side Of Energy Independence." The New York Times (2013).

Andersson, Jan Joel. The Transatlantic Relationship. Swedish Institute of International Affairs (UI), 2013.

Bacevich, Andrew. "Let Europe Be Europe: Why the United States Must Withdraw from NATO." Foreign Policy (2010).

Barcikowska, Anna. Securing the Future of European Defense. Paris: EU Institute for Security Studies, 2013.

Boskin, Michael J. Transatlantic Trade Goes Global. Project Syndicate, 2013.

Brzezinski, Zbigniew. "After America." Foreign Policy (2012): 26-29.

Caporaso, James A. "The European Union and Forms of State: Westphalian, Regulatory or Post-modern?" Journal of Common Market Studies 34, no. 1 (1996): 29-52.

China and Iran: Best Chance for a 'Multipolar' World. Stratfor, 2004.

Clinton, Hillary. "America’s Pacific Century." Foreign Policy (2011).

Conley, Heather A., and Maren Leed. NATO in the Land of Pretend. Center for Strategic and International Studies, 2013.

Cox, Michael. "No Longer Inevitable? The Transatlantic Relationship from Bush to Obama." In Europe in an Asian Century: Visions for Europe, LSE IDEAS, 22-28. London: The London School of Economics and Political Science, 2012.

Ferguson, Niall. "A World Without Power." Foreign Policy 143 (2004): 32-39.

Freedberg, Jr., Sydney J., and Colin Clark. Navy, Northrop Score Historic First With (Mostly) Successful X-47B Drone Carrier Landings. Breaking Defense, 2013.

G. Ikenberry, John. "The Rise of China and the Future of the West." Foreign Affairs 87, no. 1 (2008).

Ginsberg, Roy H.. "Conceptualizing the European Union as an International Actor: Narrowing the Theoretical Capability-Expectations Gap." Journal of Common Market Studies 37, no. 3 (1999): 429-454.

Global Trends 2030: Alternative Worlds. U.S. National Intelligence Council, 2012. 
Gnesotto, Nicole. La politique de sécurité et de défense de l'UE. Les cinq premières années (1999 - 2004). Paris: EU Institute for Security Studies, 2004.

Gordon, IV, John, and John Matsumura. The Army's Role in Overcoming Anti-Access and Area Denial Challenges. Santa Monica, CA: RAND Corporation, 2013.

Gross, Eva. The American Sequester and Us. European Union Institute for Security Studies, 2013.

Haass, Richard N. "The Second American Century? It's Already Here." Washington Post (2013).

Hendrix, Henry J. At What Cost a Carrier?. Center for a New American Security, 2013.

Hobsbawm, Eric. "War, Peace and Hegemony at the Beginning of the Twenty-First Century." In War, Peace and Hegemony in a Globalized World, 15-24. New York: Routledge, 2008.

Hooker, Richard D.. "'The Strange Voyage': A Short Précis on Strategy." Parameters 42 (2013): 59-68.

Howcroft, James. Things Americans Need to Know: How to Be Better Partners. Small Wars Journal, 2013.

Ilgen, Thomas. "The Future of the Transatlantic Partnership." In Hard Power, Soft Power and the Future of Transatlantic Relations, 195. Farnham, Surrey: Ashgate, 2006.

Iordan, Cristian. "Defending Europe." Per Concordiam 3, no. 2 (2012): 46-53.

Iordan, Cristian. "Le système européen d'acquisition d'armements. Facteur de soutien de la PESD." Romanian Journal of European Affairs 10, no. 4 (2010): 87.

J. Cole, Michael. "The DF-21D or 'Carrier Killer': An Instrument of Deception?" The Diplomat (2013).

Joyner, James. Jones: 'Pivot to Asia’ Regrettable Word Choice. New Atlanticist, 2013.

Jupille, Joseph, and James A. Caporaso. "States, Agency and Rules: The European Union in Global Environment Politics." In The European Union in the World Community, 213-229. Boulder, CO: Lynne Rienner, 1998.

Kagan, Robert. Of Paradise and Power: America and Europe in the New World Order. New York: Alfred Knopf, 2003.

Kahler, Miles. "Rising Powers and Global Governance: Negotiating Change in a Resilient Status Quo." International Affairs 89, no. 3 (2013): 711-29.

Kaldor, Mary. "A European Conception of Security." In Europe in an Asian Century: Visions for Europe, LSE IDEAS. London: The London School of Economics and Political Science, 2012.

Kaplan, Robert D. Anarchy and Hegemony. Stratfor, 2013.

Kaplan, Robert D. The Virtues of Hard Power. Stratfor, 2013. 
Keohane, Daniel. The EU's Role in East Asian Security In Look East, Act East: Transatlantic Agendas in the Asia Pacific. Paris: EU Institute for Security Studies, 2012.

Keynote speech by NATO Secretary General Anders Fogh Rasmussen at the NATO Parliamentary Assembly in Prague., 2012.

Kimmage, Michael. The Decline of the West: An American Story In Transatlantic Academy Paper Series., 2013.

Kitchen, Nicholas. The United States After Unipolarity: Executive Summary In IDEAS reports. London: London School of Economics and Political Science, 2011.

Korb, Lawrence J., Alex Rothman, and Max Hoffman. Reforming Military Compensation: Addressing Runaway Personnel Costs Is a National Imperative. Center for American Progress, 2012.

Kupchan, Charles A. "A Still-Strong Alliance." Policy Review 172 (2012).

Layne, Christopher. "From Preponderance to Offshore Balancing: America's Future Grand Strategy." International Security 22, no. 1 (1997): 86-124.

Layne, Christopher. "Offshore Balancing Revisited." The Washington Quarterly 25, no. 2 (2002): 233-248, quote on 245.

Looking Forward: U.S. National Security Beyond the Wars. In Conference organized by the Center for a New American Security, 56-63. Vol. 189 ., 2013.

Manners, Ian. "Normative Power Europe: A Contradiction in Terms?" JCMS 40, no. 2 (2002): 252-53.

Maull, H.W.. "Germany and Japan: The New Civilian Powers." Foreign Affairs 69, no. 5 (1990): 92-93.

Mazarr, Michael J.. Discriminate Power: A Strategy for a Sustainable National Security Posture In The Philadelphia Papers. NDU Strategy Study Group, 2013.

Mearsheimer, John J.. The Tragedy of Great Power Politics. New York: Norton, 2001.

Missiroli, Antonio. Enabling the Future European Military Capabilities 2013-2025: Challenges and Avenues. Paris: EU Institute for Security Studies, 2013.

Missiroli, Antonio. Strategic Foresight and the EU. Paris: EU Institute for Security Studies, 2013.

Nye, Joseph S. "The Future of American Power." In War, Peace and Hegemony in a Globalized World, 36-49. New York: Routledge, 2008.

Nye, Joseph S. Soft Power: The Means to Success in World Politics. New York: PublicAffairs, 2004.

Nye, Joseph S. The Future of Power. New York: PublicAffairs, 2011.

Nye, Joseph. "Soft Power and European-American Affairs." In Hard Power, Soft Power and the Future of Transatlantic Relations, 25-35. Farnham, Surrey: Ashgate, 2006. 
Overview - United States Department of Defense Fiscal Year 2013 Budget Request. Washington, D.C.: U.S. Department of Defense, 2012.

Parsi, Vittorio. The Inevitable Alliance: Europe and the United States Beyond Iraq. London: Palgrave Macmillan, 2006.

Petiteville, Franck. "L’Union Européenne comme acteur international 'global.' Un agenda de recherche." Revue Internationale et Stratégique 47, no. 3 (2002): 145-57.

Petiteville, Franck. La politique internationale de l'Union Européenne. Paris: Presses Sciences Po, 2006.

Posen, Barry R. "Pull Back: The Case for a Less Activist Foreign Policy." Foreign Affairs 92, no. 1 (2013).

Rhodes, Matthew. "U.S. perspectives on NATO." In Understanding NATO in the 21st Century, 33-49. New York: Routledge, 2013.

Roulo, Claudette. Hagel Meets with Troops on Fort Bragg, Discussed Budget. U.S. Department of Defense Website, 2013.

Rytz, Henriette. The Pivot to Asia - Overcoming a Communication Problem. German Institute for International and Security Affairs (SWP), 2013.

Serfaty, Simon. "The Folly of Forgetting the West." Policy Review 174 (2012).

Sharma, Ruchir. "Broken BRICs: Why the Rest Stopped Rising." Foreign Affairs (2012): 2-7.

SIPRI Yearbook 2013: Armaments, Disarmament and International Security. Stockholm: SIPRI, 2013.

Smith, Karen. "The End of Civilian Power EU: A Welcome Demise or Cause for Concern?" The International Spectator 35, no. 2 (2000): 11-28.

Tata, Samir. "Recalibrating American Grand Strategy: Softening U.S. Policies Toward Iran in order to Contain China." Parameters 42/43 (2013): 47-58.

Vezirgiannidou, Sevasti-Eleni. "The United States and Rising Powers in a Posthegemonic Global Order." International Affairs 89, no. 3 (2013): 635-51.

Volker, Kurt. "Reaffirming Transatlantic Unity." Policy Review 172 (2012).

Williamson, Wade. Combating Emerging Threats Through Security Collaboration. Security Week, 2012.

Zakheim, Dov S. "The Strategic Implications of a Freefalling U.S. Defense Budget." The American Interest (2013): 43-51.

Zapolskis, Martynas. "NATO'S Strategic Challenges: The Alliance Strives to Maintain Integrity in an Uncertain Global Environment." Per Concordiam 4, no. 2 (2013): 24-29. 